\title{
THE RELATIONSHIP OF ENERGY INTAKE, PROTEIN, VITAMIN B6, VITAMIN C WITH THE NUTRITIONAL STATUS OF LUNG TUBERCULOSIS PATIENTS IN THE KEMUNING ROOM, Dr. M. YUNUS BENGKULU IN 2020
}

\author{
Dita Kodrati Alaina $^{1)}$, Desri Suryani ${ }^{2)}$, Afriyana Siregar ${ }^{3)}$ \\ ${ }^{1}$ Prodi Sarjana Terapan Gizi Dan Dietetika, Jurusan Gizi Poltekkes \\ Kemenkes Bengkulu, Jl. Indragiri No. 03, Bengkulu, 38225 \\ ${ }^{2,3}$ Poltekkes Kemenkes Bengkulu J1. Indragiri No. 03, Bengkulu, 38225 \\ E-mail: ditakodratialaina@gmail.com
}

Submitted: $10^{\text {th }}$ July 2020; Accepted: $29^{\text {th }}$ November 2021

https://doi.org/10.36525/sanitas.2021.14

\begin{abstract}
Weight loss and appetite often occur in pulmonary TB patients. One of the determinants of pulmonary TB disease is infection and nutritional status. Pulmonary TB patients have decreased nutritional status due to the level of behavior towards food and health, especially the adequacy of energy and protein. The purpose of this study was to determine the relationship of energy intake, protein, vitamin B6, vitamin C and nutritional status in pulmonary tuberculosis patients in Dr. M Yunus Bengkulu General Hospital in 2020. The method was observed analytic with cross sectional approach. The sampling technique was taken through accidental sampling method with a sample of 35 patients. Data collection of nutrient intake with semi food frequency questionnaire (FFQ) method and 1 24 hour recall. Univariate and bivariate data analysis used the Spearman Correlation test. The results showed the average intake of energy, protein, vitamin B6, and vitamin C was less than the nutritional adequacy rate (RDA). There is a relationship between energy intake and nutritional status, There is no relationship between protein intake and nutritional status, there is no relationship between vitamin B6 intake and nutritional status, there is no relationship between vitamin C intake and nutritional status. It is expected that pulmonary TB patients can increase their energy intake from carbohydrate, protein, and fat sources to avoid malnutrition.
\end{abstract}

Keywords: intake, nutritional status, tuberculosis

This is an open access journal, and articles are distributed under the terms of the Creative Commons Attribution-Non Commercial-Share Alike 4.0 License, which allows others to remix, tweak, and build upon the work non-commercially, as long as appropriate credit is given and the new creations are licensed under the identical terms.

CO2021 Sanitas 


\title{
HUBUNGAN ASUPAN ENERGI, PROTEIN, VITAMIN B6, VITAMIN C DENGAN STATUS GIZI PASIEN TUBERKULOSIS PARU DI RUANGAN KEMUNING RSUD Dr. M. YUNUS BENGKULU TAHUN 2020
}

\begin{abstract}
ABSTRAK
Penurunan berat badan dan nafsu makan seringkali terjadi pada pasien TB paru. Determinan penyakit TB paru salah satunya infeksi dan status gizi. Pasien TB paru mengalami penurunan status gizi disebabkan tingkat perilaku terhadap makanan dan kesehatan, khususnya kecukupan energi dan protein. Tujuan penelitian untuk mengetahui hubungan asupan energi, protein, vitamin B6, vitamin C dengan status gizi pada pasien tuberkulosis paru di RSUD Dr M Yunus Bengkulu tahun 2020. Metode penelitian merupakan observasional analitik dengan pendekatan cross sectional. Teknik pengambilan sampel dengan metode accidental sampling dengan jumlah sampel 35 pasien. Pengumpulan data asupan zat gizi dengan metode semi food frequency questionnaire (FFQ) dan recall 1×24 jam. Analisis data secara univariat dan bivariat menggunakan uji spearman correlation. Hasil penelitian menunjukkan rata-rata asupan energi, protein, vitamin B6, dan vitamin $\mathrm{C}$ kategori kurang dari angka kecukupan gizi (AKG). Terdapat hubungan antara asupan energi dan status gizi, tidak terdapat hubungan antara asupan protein dan status gizi, tidak terdapat hubungan antara asupan vitamin B6 dengan status gizi, tidak terdapat hubungan antara asupan vitamin C dan status gizi. Diharapkan kepada pasien TB paru dapat meningkatkan asupan energi dari sumber karbohidrat, protein, dan lemak agar terhindar dari kekurangan gizi.
\end{abstract}

Kata Kunci: asupan, status gizi, tuberkulosis

\section{PENDAHULUAN}

Penyakit tuberkulosis merupakan penyakit menular yang masih menjadi masalah kesehatan masyarakat, dimana menyebabkan jutaan orang meninggal setiap tahun akibat Tuberkulosis (TB). Menurut badan kesehatan dunia World Health Organization (WHO) TB adalah salah satu dari 10 penyebab kematian terbesar di dunia. Selain itu juga TB paru merupakan salah satu pembunuh utama pada pengidap human immunodeficiency virus (HIV) acquired immunodeficiency syndrome (AIDS).(12)

Kematian akibat tuberkulosis diperkirakan sebanyak 1,3 juta kematian ditambah 374.000 pada orang dengan HIV positif. Indonesia merupakan negara dengan jumlah kasus baru terbanyak kedua di dunia setelah India. Tahun 2015 jumlah kasus tuberkulosis yang ditemukan di Indonesia sebesar 330.729, meningkat menjadi 351.893 pada tahun 2016, dan meningkat kembali menjadi 420.994 kasus pada tahun 2017 (WHO, 2019). Status gizi seseorang dipengaruhi oleh asupan energi, protein, vitamin dan zat gizi yang lain. Asupan energi merupakan asupan utama yang dibutuhkan oleh tubuh untuk melakukan aktivitas. Kurangnya asupan energi dapat menyebabkan keseimbangan dan kerja otot sehingga tubuh akan mudah lelah.(2)

Keadaan kurang gizi, defisiensi makronutrien dan mikronutrien, penurunan berat badan dan penurunan nafsu makan seringkali terjadi pada pasien TB paru. Determinan penyakit TB paru salah satunya adalah infeksi dan status gizi. Pasien TB paru mengalami 
penurunan status gizi disebabkan tingkat perilaku terhadap makanan dan kesehatan, khususnya kecukupan energi dan protein, lama menderita penyakit paru, serta pendapatan perkapita pasien (20). Vitamin B6 (Piridoksin) berfungsi untuk mencerna protein, sintesis antibodi, dan berperan dalam pembentukan sel darah merah. Kekurangan vitamin B6 akibat mengkonsumsi obat anti TBC yaitu Isoniazid akan menyebabkan gangguan metabolisme protein seperti lemah, dan mudah tersinggung serta berdampak pada hilangnya massa otot (wasting).(3)

Aibana (1) menyatakan vitamin sangat berhubungan dengan kekebalan dan gizi termasuk vitamin $\mathrm{C}$, kekurangan vitamin dapat memengaruhi kekebalan tubuh terhadap berbagai penyakit menular termasuk tuberkulosis, kekurangan vitamin sering terjadi pada pasien dengan tuberkulosis. Provinsi Bengkulu merupakan provinsi kabupaten/kota yang menyumbang angka kejadian tuberkulosis yang cukup tinggi, berdasarkan riwayat diagnosis dokter menurut provinsi, provinsi Bengkulu menduduki peringkat ke-10 se-Indonesia penyakit TB paru terbanyak.(13)

Berdasarkan data yang diperoleh di RSUD Dr. M. Yunus sebanyak 155 kasus (Dinkes Bengkulu, 2019). Survei pendahuluan terhadap 10 pasien di ruang Kemuning RSUD Dr. M. Yunus Bengkulu, terdapat 5 orang $(50 \%)$ mempunyai status gizi normal,1 orang $(10 \%)$ mempunyai status gizi overweight, dan 4 orang (40\%) mempunyai status gizi underweight. Untuk asupan makan, dari 10 responden terdapat 4 orang (40\%) dengan asupan makan yang kurang ( $<70 \%$ dari total kebutuhan sehari), dan 6 orang dengan asupan makan yang cukup ( $\geq 70 \%$ dari total kebutuhan sehari). Berdasarkan latar belakang tersebut, maka rumusan masalah dalam penelitian ini adalah "Bagaimana hubungan asupan energi, protein, vitamin B6, vitamin C dengan status gizi pasien TB Paru di ruangan Kemuning RSUD Dr. M. Yunus Bengkulu tahun 2020".

Tujuan penelitian adalah mengetahui hubungan asupan energi, protein, vitamin B6, vitamin $\mathrm{C}$ dengan status gizi pasien TB paru di ruangan Kemuning RSUD Dr. M. Yunus Bengkulu tahun 2020.

\section{METODE PENELITIAN}

Desain penelitian menggunakan observasional kuantitatif dengan pendekatan cross sectional. Penelitian dilakukan di ruang Kemuning RSUD Dr. M. Yunus Bengkulu. Sampel sebanyak 35 orang dilakukan secara accidental sampling, Pengambilan sampel dilakukan dengan kriteria inklusi sebagai berikut: Pasien TB Paru $(+)$ dewasa berusia $>18$ 
tahun, telah mendapatkan pengobatan TB Paru. Kriteria eksklusi subjek menolak wawancara, keadaan sudah sembuh, keadaan hamil atau menyusui. Pengumpulan data dilakukan dengan cara pengukuran IMT menggunakan alat timbangan dan meteran serta lembar semi FFQ dan Recall 1x24 jam.

Tahap pelaksanaan dalam pengumpulan data, Peneliti mendatangi subjek yang bersedia menjadi responden dilakukan pengukuran IMT, kemudian responden menandatangani informed consent yang telah disiapkan peneliti. Seluruh data yang terkumpul selanjutnya dimasukkan (entry) dan ditabulasi. Analisis data menggunakan uji korelasi. Dilakukan uji normalitas data untuk mengetahui apakah data berdistribusi normal atau tidak. Jika data terdistribusi normal maka dilakukan uji korelasi Spearman Rank apabila memiliki nilai $\mathrm{p}<0,05$ dan berdistribusi tidak normal apabila nilai $\mathrm{p}>0,05$. Uji normalitas dalam penelitian ini menggunakan kolmogrov smirnov. Penelitian ini dilaksanakan karena menyangkut keamanan dan kesejahteraan manusia sebagai subjek penelitian kesehatan maka penelitian ini sudah memperoleh ethical approval (persetujuan etik).

\section{HASIL DAN PEMBAHASAN}

Rata-rata asupan energi pasien TBC di ruang kemuning RSUD Dr. M. Yunus Bengkulu 397,05 kkal/hari, asupan energi pasien lebih rendah dibanding kebutuhan energi sehari yaitu $2150 \mathrm{kkal} / \mathrm{hari}$. Asupan protein rata-rata 24,6 g/hari lebih rendah dibanding kebutuhan protein sehari yaitu $65 \mathrm{~g} /$ hari. Asupan Vitamin B6 pasien TBC rata-rata 0,56 $\mathrm{mg} /$ hari lebih rendah dibanding kebutuhan vitamin B6 sehari yaitu 1,3 mg/hari. Rata-rata asupan vitamin $\mathrm{C}$ pasien $\mathrm{TBC}$ yaitu $37,2 \mathrm{mg}$, asupan vitamin $\mathrm{C}$ lebih rendah bila dibandingkan dengan kebutuhan vitamin C dalam sehari yaitu $90 \mathrm{mg} /$ hari.

\section{Tabel 1. Distribusi Asupan Gizi Pasien TBC di RSUD Dr. M. Yunus} Kota Bengkulu

\begin{tabular}{lrrrr}
\hline Variabel & \multicolumn{1}{c}{ Mean } & \multicolumn{1}{c}{ SD } & \multicolumn{1}{c}{ Min } & \multicolumn{1}{c}{ Max } \\
\hline Energi & 397,04 & 205 & 110,8 & 1013 \\
Protein & 24,61 & 9,91 & 10,3 & 51,6 \\
Vitamin B & 0,56 & 0,19 & 0,2 & 1,2 \\
Vitamin C & 37,16 & 18,60 & 1,6 & 81,3 \\
\hline
\end{tabular}

Sumber: Hasil Penelitian

Rata-rata IMT pasien TBC adalah $17,8 \mathrm{~kg} / \mathrm{m}^{2}$ termasuk dalam kategori status gizi kurang karena masih di luar rentang IMT normal yaitu $18-24,9 \mathrm{~kg} / \mathrm{m}^{2}$. Indeks massa tubuh pasien TBC paling kecil adalah $11,3 \mathrm{~kg} / \mathrm{m}^{2}$ dan paling besar adalah $253 \mathrm{~kg} / \mathrm{m}^{2}$ berbeda dengan penelitian yang dilakukan Dewi \& Istianah (2018) lebih banyak subjek penelitian 
memiliki status gizi lebih dengan IMT $>25 \mathrm{~kg} / \mathrm{m}^{2}$ sebanyak $(65,3 \%)$ dan penelitian terhadap mahasiswa di Bengkulu yang dilakukan Frovela, dkk (2020) bahwa rata-rata IMT pada mahasiswa termasuk dalam kategori status gizi normal. Penelitian ini menunjukkan bahwa rata-rata IMT responden kurang, jika seseorang dikatakan dalam kategori terkena gizi kurang, maka akan terjadi penurunan imunitas tubuh dan mengakibatkan fungsi dalam membentengi diri terhadap infeksi menjadi menurun.

Tabel 2. Distribusi IMT Pasien TBC di RSUD Dr. M. Yunus Kota Bengkulu

\begin{tabular}{lllll}
\hline Variabel & Mean & Median & Min & Maks \\
\hline IMT & 17,8 & 18,3 & 11,3 & 25,3 \\
\hline
\end{tabular}

Sumber: Hasil Penelitian

\section{Hubungan Asupan zat gizi dengan Status Gizi pada pasien TB Paru}

\begin{tabular}{lcc}
\multicolumn{3}{l}{ Tabel 3 Hubungan Asupan energi, protein, vitamin B6, vitamin C dengan } \\
status gizi Pasien TBC di RSUD Dr. M. Yunus Kota Bengkulu \\
\hline \multicolumn{1}{c}{ Variabel } & R & R P \\
\hline Asupan energy & 0,348 & 0,041 \\
Asupan protein & 0,14 & 0,422 \\
Asupan vitamin B6 & $-0,143$ & 0,414 \\
Asupan Vitamin C & 0,094 & 0,589
\end{tabular}

Sumber: Hasil Penelitian

Tabel 3 menunjukkan bahwa terdapat hubungan antara asupan energi dengan status gizi didapatkan hasil $p$-value 0,041 , hubungan yang sedang $(\mathrm{r}=0,348)$. Tidak terdapat hubungan antara asupan protein dengan status gizi $p$-value 0,422 , tidak ada hubungan vitamin B6 dengan status gizi p-value 0,414 dan tidak ada hubungan antara asupan vitamin $\mathrm{C}$ dengan status gizi $p$-value 0,589 .

\section{Hubungan Asupan Energi dengan Status Gizi Pasien TB Paru di Ruang Kemuning RSUD Dr. M. Yunus Bengkulu}

Berdasarkan uji statistik terdapat hubungan antara asupan energi dengan status gizi pasien TBC paru di ruang Kemuning RSUD Dr. M. Yunus Bengkulu diperoleh menunjukkan bahwa kekuatan hubungan yang rendah dan berpola positif artinya semakin tinggi asupan energi maka semakin tinggi status gizi. Sejalan dengan penelitian Rahmisari,(17) ada hubungan antara asupan energi dengan status pasien TB Paru dengan hubungan cukup kuat. Berdasarkan grafik scatter plot diketahui bahwa semakin tinggi asupan energi pada pasien TB paru maka status gizinya semakin baik. Penelitian Dewi (8) pada pegawai Direktorat 
Poltekkes Kemenkes Jakarta II menyatakan terdapat hubungan antara asupan energi dengan status gizi. Berdasarkan penelitian Frediani (10), bahwa. hubungan antara status gizi dan TB tidak ada cukup bukti untuk menentukan apakah peningkatan asupan energi meningkatkan status gizi pasien TB paru.

Menurut Puspita (9), penurunan status gizi sampai kondisi malnutrisi sering terjadi pada pasien TB paru, terutama jika tidak mendapatkan kecukupan energi dan protein. Ratarata asupan energi pada pasien TB Paru di ruang kemuning RSUD Dr. M. Yunus Bengkulu adalah 397 kalori dengan rata-rata IMT pada pasien TB adalah 17,8 kg/m², masuk dalam kategori kurang, asupan energi pasien TB paru lebih rendah dibanding kebutuhan energi sehari pada umumnya karena asupan makan penderita TB paru cenderung lebih rendah dibandingkan orang sehat.

Penderita TB paru, kekurangan gizi akan mempengaruhi penurunan nafsu makan, malabsorbsi danmenyebabkan anabolisme yang dapat mengakibatkan terjadinya wasting. Kekurangan energi protein (KEP) dan defisiensi zat gizi mikro akan meningkatkan resiko terjangkit TB paru. Dibuktikan bahwa penderita TB paru, KEP akan mengalami keterlambatan proses kesembuhan dan tingkat kematiannya lebih tinggi dibanding penderita TB paru dengan status gizi baik.(14)

\section{Hubungan Asupan Protein dengan Status Gizi Pasien TB Paru di Ruang Kemuning RSUD Dr. M. Yunus Bengkulu}

Tidak terdapat hubungan antara asupan protein dengan status gizi pasien TB Paru di ruang Kemuning RSUD Dr. M. Yunus Bengkulu dengan p-value 0,422. Penelitian ini tidak sejalan dengan penelitian yang dilakukan oleh Rahmisari (17) bahwa terdapat hubungan asupan protein dengan status gizi pasien TB paru. Penelitian Dewi \& Istianah (8) menyatakan terdapat hubungan yang signifikan antara asupan protein dengan status gizi.

Tidak adanya hubungan asupan protein dengan status gizi dapat dimungkinkan oleh karena asupan protein sangat berkaitan erat dengan pengaruh asupan zat gizi lainnya, serta banyaknya faktor yang mempengaruhi seperti faktor bakteri TB, dan infeksi yang menyebabkan energi total pasien cenderung meningkat menyebabkan kebutuhan sumber energi harus terpenuhi dari segala sumber seperti karbohidrat, protein, dan lemak yang dapat menyumbang kebutuhan energi, yang mana ketika pasien kurang mengkonsumsi sumber protein namun cukup mengkonsumsi sumber energi lain seperti karbohidrat dan lemak maka 
energinya tetap terpenuhi dan tidak akan terjadi wasting, serta tidak akan tampak adanya hubungan.

Rata-rata asupan protein pada penelitian ini adalah 24,61 gram dalam kategori kurang seperti halnya pada penelitian Nthiga,(15) menunjukkan sebagian besar subyek penelitian yaitu pasien tuberkulosis memiliki asupan protein yang kurang bila dibandingkan dengan kebutuhan asupan protein masing-masing pasien. Asupan protein dan kalori total yang tidak adekuat umum pada pasien TB paru. Temuan ini konsisten dengan penelitian sebelumnya di Cina. Asupan energi yang kurang mengakibatkan pemecahan protein menjadi glukosa melalui proses glukoneogenesis. Asupan protein yang kurang mengakibatkan pembentukan enzim,albumin dan imunoglobulin menjadi terganggu.(9) Sejalan dengan penelitian (19) yang menunjukkan bahwa rata-rata asupan protein responden masih di bawah rata-rata angka kecukupan gizi.

\section{Hubungan Asupan Vitamin B6 dengan Status Gizi Pasien TB Paru di Ruang Kemuning RSUD Dr. M. Yunus Bengkulu}

Tidak terdapat hubungan antara asupan vitamin B6 dengan status gizi pasien TB paru di ruang kemuning RSUD Dr. M. Yunus Bengkulu. Hasil penelitian didukung dengan penelitian oleh Septiana (3), mengatakan bahwa tidak ada hubungan tingkat kecukupan vitamin B6 dengan status antropometri pasien TB Paru. Rata-rata asupan vitamin B6 pasien TB paru adalah 0,557 mg dengan rata-rata IMT pada pasien adalah $17,84 \mathrm{~kg} / \mathrm{m}^{2}$, masuk dalam kategori kurang.(21)

Penelitian Nthiga,(15) menyatakan bahwa adanya hubungan sebab vitamin B6 kurang dikarenakan efek samping dari konsumsi Isoniazid, serta kurangnya asupan makanan sumber vitamin B6, yang secara tidak langsung akan menyebabkan gangguan metabolisme protein seperti lemah, dan mudah tersinggung serta hilangnya massa otot (wasting). Defisiensi vitamin B6 yang terjadi pada pasien dapat dikarenakan kurangnya asupan makanan sumber vitamin B6 karena ada kurangnya pengetahuan dan nafsu makan. Selain itu vitamin B6 jumlahnya sangat kecil di bahan makanan dan biasanya dapat diatasi dengan pemberian tablet vitamin B6 untuk menghindari defisiensi selama mengkonsumsi Isoniazid. Asupan vitamin B6 pasien TB paru lebih rendah jika dibandingkan dengan asupan vitamin B6 yang dianjurkan pada umumnya yang berkisar 1,3 mg. Sumber vitamin B6 yang dihidangkan di rumah sakit seperti: kentang, pisang, bayam, papaya, ikan, tenggiri sedangkan yang tidak tersaji yaitu seperti hati sapi, kacang tanah, ragi, ikan trout, ikan salmon dan alpukat. 


\section{Hubungan Asupan Vitamin C dengan Status Gizi Pasien TB Paru di Ruang Kemuning RSUD Dr. M. Yunus Bengkulu}

Tidak terdapat hubungan antara asupan vitamin $\mathrm{C}$ dengan status gizi pasien TB paru di ruang Kemuning RSUD Dr. M. Yunus Bengkulu. Berbeda dengan penelitian yang dilakukan oleh Rahmisari (17) bahwa tidak ada hubungan antara asupan vitamin C dengan status gizi pasien TB Paru. Sejalan dengan penelitian Gannika (12) yang menyatakan tidak ada hubungan antara asupan vitamin $\mathrm{C}$ dengan status gizi, namun vitamin $\mathrm{C}$ merupakan zat gizi yang dibutuhkan untuk memperkuat sel imun dalam melawan dan menetralkan radikal bebas sehingga mencegah terjadinya infeksi. Rata-rata asupan vitamin $\mathrm{C}$ pada komunitas pasien TB paru adalah 37,16 mg dengan rata-rata IMT pada pasien TB paru di ruang Kemuning RSUD Dr.M.Yunus Bengkulu adalah 17,84 kg/m², masuk dalam kategori status gizi kurang.(21)

Asupan vitamin C pasien TB paru lebih rendah jika dibandingkan dengan asupan vitamin C pada umumnya berkisar $90 \mathrm{mg}$. Sama halnya dengan penelitian Septiana,(3) rendahnya asupan vitamin $\mathrm{C}$ di banding angka kecukupan gizi (AKG) disebabkan oleh kurangnya asupan sumber vitamin $\mathrm{C}$ karena rendahnya daya beli buah dan sayur dari pasien dengan TB paru yang dominan dari mereka memiliki status ekonomi menengah ke bawah. Sumber vitamin C banyak terkandung di buah dan sayur seperti: jambu biji, papaya, jeruk, stroberi, nenas, mangga, daun kelor, dan brokoli yang terbatas dikonsumsi oleh pasien karena terbatasnya variasi lauk dan buah yang tersedia dan jumlahnya yang tidak memenuhi kebutuhan vitamin C pasien selama di rumah sakit. Selain itu nafsu makan pasien TB paru yang cenderung menurun sebagai faktor dari obat anti TB paru seperti isoniazid yang juga membuat asupan sumber vitamin C menjadi rendah. Menurut Nugroho (16) vitamin C dapat meningkatkan daya tahan tubuh yaitu dapat meningkatkan fungsi sel darah putih. Vitamin $\mathrm{C}$ dapat menghentikan penyebaran infeksi termasuk TB paru, serta mempercepat pemulihan tuberkulosis dengan menyembuhkan rongga pembusukan dan mengubah bacillus fast sputum acid (AFB) negatif, vitamin $\mathrm{C}$ telah terbukti memiliki kemampuan untuk membunuh mycobacterium tuberculosis yang resisten terhadap obat.(5)

\section{SIMPULAN}

Rata-rata asupan energi 397 kalori, asupan protein 24,6 gram, asupan vitamin B6 0,557 mg, asupan vitamin C 37,16 mg. Status gizi pasien adalah $17,84 \mathrm{~kg} / \mathrm{m}^{2}$ dengan status gizi termasuk kategori kurang, Terdapat hubungan antara asupan energi terhadap status gizi, tidak ada hubungan antara asupan protein terhadap status gizi, tidak ada hubungan antara 
asupan vitamin B6 terhadap status gizi, tidak ada hubungan antara asupan vitamin $\mathrm{C}$ terhadap status gizi. Pasien TBC di ruang kemuning RSUD Dr. M. Yunus Bengkulu.

\section{UCAPAN TERIMA KASIH}

Mengucapkan terima kasih kepada RSUD Dr. M. Yunus Bengkulu yang telah memfasilitasi tempat penelitian ini.

\section{DAFTAR PUSTAKA}

1. Aibana, O., Franke, M. F., Huang, C. C., Galea, J. T., Calderon, R., Zhang, Z., Becerra, M. C., Smith, E. R., Ronnenberg, A. G., Contreras, C., Yataco, R., Lecca, L., \& Murray, M. B. (2017). Impact of Vitamin A and carotenoids on the risk of tuberculosis progression. Clinical Infectious Diseases, 65(6), 900-909.

2. Andayani, S., \& Astuti, Y. (2017). Prediksi Kejadian Penyakit Tuberkulosis Paru Berdasarkan Usia Di Kabupaten Ponorogo Tahun 2016-2020. Indonesian Journal for Health Sciences, 1(2), 29-33.

3. Anggriani Septiana,Suyatno, M. I. K. (2017). Jurnal Kesehatan Masyarakat, 6(1),1-11.

4. Astuti, T, Febriansyah. Fitness Level Of High School Students Based On Smoking Habits, Nutrient Intake, Physical Activity And Nutritional Status. Sanitas: Jurnal Teknologi Dan Seni Kesehatan. Vol. 08 No. 02, 2017, 114-122.

5. Banerjee, D. (2014). Vitamin Deficiency and Tuberculosis: Need for Urgent Clinical Trial for Managment of Tuberculosis. Journal of Nutritional Health \& Food Science, 2(1).

6. Chakraborty,S.,Syal,K.,Bhattacharyya, R., \& Banerjee, D. (2014). Vitamin Deficiency and Tuberculosis : Need for Urgent Clinical Trial for Managment of Tuberculosis.

7. Dinkes Bengkulu. (2019) https://www.kemkes.go.id/resources/download/ profil/PROFIL_KES_PROVINSI_2018/07_Bengkulu_2018.

8. Dewi, N., Istianah, I., Gizi, J., Tinggi, S., \& Kesehatan, I. (2018). Activities With Nutrition Status In Employee Offices Of The Poltekkes Kemenkes Jakarta Ii Pendahuluan Indonesia saat ini sedang Kesehatan penelitian RI sekitar Pada tersebut memperlihatkan mengalami masalah gizi ganda, dimana masalah gizi kurang yang bel. Jurnal Teknologi Dan Seni Kesehatan, 09, 143-151.

9. Elsa Puspita, Erwin Christianto, I. Y. (2016). Journal of Chemical Information and Modeling, 3(2),1-2.

10. Frediani,J.K.,Tukvadze,N.,Sanikidze,E.,Kipiani,M.,Hebbar,G.,Easley,K.A.,Shenvi,N.,R amakrishnan,U.,Tangpricha,V., Blumberg, H. M., \& Ziegler, T. R. (2013). A culturespecific nutrient intake assessment instrument in patients with pulmonary tuberculosis.ClinicalNutrition,32(6),1023-1028.

11. Frovela, T., Suryani, D., dan Wahyu, T., Relationship Of Knowlwdge, Attitudes And Behavior About Nutrition Balance With Nutritional Status Of Student In Poltekkes Kemenkes Bengkulu In 2020 Sanitas: Jurnal Teknologi Dan Seni Kesehatan. 2020. Vol. $11(2): 158-166$.

12. Gannika,L.(2016).Microbacterium Tuberkulosis Paru. 1, 909 - 916 .Global TUBERCULOSIS. (2018).

13. Kemenkes RI. (2018). Data dan Informasi profil Kesehatan Indonesia 2018.

14. Krishna Bihari Gupta, Rajesh Gupta,Atulya Atreja, S. V. (2009). Tuberculosis and nutrition. Deutsches Medizinisches Journal,12, 145-149.

15. Nthiga, I., Mbithe, D., Mugendi, B., Nyangaresi, D., \& Wambui, T. (2017). Dietary 
practices of pulmonary tuberculosis patients attending clinic at lodwar county and referral. International Journal of Food Science and Nutrition, 2(1), 123-127.

16. Nugroho, E. J. (2012). Pengaruh Pemberian Vitamin C terhadap Nilai Limfosit pada Pasien Tuberculose di Wilayah Kerja Puskesmas Kradenan Kabupaten Grobogan. 1-13.

17. Rahmisari, Y. (2018). Hubungan Tingkat Pengetahuan Gizi,Asupan Energi,Protein, Vitamin A dan Vitamin C dengan Status Gizi Pasien TB Paru di Klinik Paru dan TB RSUD Dr M Ashari Pemalang.

18. Rao,T.S.S.,Asha,M.R.,Ramesh,B.N.,\& Rao, K. S. J. (2020). Understanding nutrition, depression and mental illnesses.50(2), 77-82.

19. Trina Astuti, F. (2017). Fitness Level Of High School Students Based On Smoking Habits, Nutrient Intake, Physical Activity And Nutritional Status. Jurnal Teknologi Dan Seni Kesehatan, 8843, 114-121.

20. Widiastuti, Y., S.S, D., \& Sofro, M. A. U. (2019). Pengaruh Supplementasi Probiotik Dan Selenium Terhadap Respon Imun Nlr (Neutrophil Lymphocyte Count Ratio), Haemoglobin Dan Albumin Pada Tikus Wistar Yang Diinduksi Mycobakterium Tuberculosis. Journal of Nutrition College, 8(1), 38.

21. WHO.(2018).GLOBAL.TUBERCULOSIS REPORT 2019.

22. Zhang, Z., \& Becerra, M. C. (2017). Impact of Vitamin A and Carotenoids on the Risk of Tuberculosis Progression Impact of Vitamin A and Carotenoids on the Risk of Tuberculosis Progression. 